possibly in the case of Plasmodium malarice, none of the malarial parasites in man has been established in laboratory animals. The tests used, nevertheless, are unlikely to pass over any compound of potential value in man. Dr. Ann Bishop pointed out that quinine gives rise to little or no drug resistance, and with pamaquin only a very slight increase can be induced. Proguanil, however, readily induces resistance in Plasmodium gallinaceum; strains treated with sulphadiazine or sulphanilamide become resistant to themselves and to proguanil. Metachloridine also induces a high degree of drug resistance in malarial parasites. In testing for ability to produce drug resistance, experimental strains of the parasite must be maintained in a state of acute infection. Results from tests upon latent infections are not comparable and are difficult to evaluate.

Dr. F. Hawking urged that when a compound has once been shown to be effective in the laboratory, it should be tested as soon as possible in man in order to bring to light toxic reactions which cannot be elicited in laboratory animals.

\section{IMPORTANCE OF SCIENCE IN AMERICAN EDUCATION}

TN a paper contributed to Science $(113,2945$; June 1 8, 1951) Ernst A. Hauser, of the Massachusetts Institute of Technology and the Worcester Polytechnic Institute, suggests that most of the advances in science in pure or fundamental research have been made by citizens of countries other than the United States or by American citizens who have received their education in Europe or by Europeans who have emigrated to the United States. In a supporting statement, Hauser quotes the president of the American Society of Mechanical Engineers, who recently declared that the American failure to recognize and respond to their particular responsibilities as citizens and human beings and their failure to understand that technical progress is not enough is the key to many of the greatest difficulties in America to-day. Recently, the United States Commissioner of Education has also directed attention to the fact that a great number of educational institutions still organize their curricula in watertight compartments, and that all efforts to penetrate the barriers between departments are jealously resisted.

In an attempt to discover the weaknesses in the science side of American education, Hauser compares a German and an American university. In the latter the student is permitted to devote himself to a specialized branch of science or technology far too early, so that the last college years are used as preparation for an advanced specialized education, thereby cutting down the time that should be devoted to general education. Another essential difference between American training technique and that used in Europe is that Americans use systematic drilling as a method of instruction; this can provide sound knowledge, but is scarcely likely to promote self reliant thinking and the spirit of research. The excessive use of the text-book may also be criticized because it works in the same direction. Throughout most of Europe only those who have graduated from the Gymnasium or Realschule may enrol in a university or comparable technological institute. When gradu- ating from one of these schools, which they have had to attend for eight years (having left the grammar school at about ten or eleven), students have acquired a background of general education at least comparable to that of American students starting the junior year in college.

Hauser suggests that what is needed in American education is to offer all students a more general appreciation of what science actually stands for. With J. B. Conant he agrees that the objective should be to give a greater degree of understanding of science by the close study of a relatively few historical examples of the development of science. Case-histories; he suggests, would almost all be chosen from the early days in the evolution of the modern discipline, as, for example, certain aspects of chemistry in the eighteenth and nineteenth centuries. The advantages of this method of approach are two-fold : first, relatively little factual knowledge is required either of the science in question or other sciences, and relatively little mathematics; second, in the early days one sees in clearest light the necessary fumblings of even intellectual giants when they were also pioneers; one comes to understand what science is by seeing how difficult it is in fact to carry out pretentious scientific precepts.

Hauser also concurs with I. B. Cohen, of Harvard, who quite recently said that students could be given a general appreciation of what science stands for by making them more familiar with the human side of those to whom we owe the greatest discoveries in science, and with the circumstances that led to the accomplishments for which they are now famous.

\section{CURRENT TRENDS IN GENERAL PSYCHOLOGY}

$T$ HE programme for the morning session on August 9 of Section J (Psychology) of the British Association consisted of three papers discuss. ing tendencies in general psychology. The discussion presents certain difficulties to anyone attempting to summarize it, in that the three papers were diverse in content. Prof. R. C. Oldficld was concerned with experiment in psychology; Prof. A. Rex Knight and Mr. A. J. Laird with motivation; while the present writer dealt with the teaching of psychology. Instead of a summary, therefore, an attempt will be made to discuss rather generally certain tendencies in present-day psychology which the papers seemed to reveal.

It is clear that, by the middle of the present century, psychology has outgrown certain early phases. These phases were first of all the period of the 'schools', when psychologists carried on the disputative traditions of their philosophical predecessors. There followed a phase of rather indiscriminate experimentation which was corrected after a time by a preoccupation with problems of method. More recently there has been a tendency for those interested in theory and experiment to dissociate them. selves from the testers and statisticians, on one hand, and the clinicians, on the other. To-day, however, there is a considerable measure of unity, and experimental techniques are being used which are varied and flexible enough to cope with a wide range of problems. 
Prof. Oldfield mentioned two investigations which show the present-day trend. In the first, attempts are being made to use rather complicated mathematical tools in describing the behaviour of a mazerunning animal at a point of choice; and in the second, an analysis is being made, again using quite advanced mathematics, of certain visual illusions first investigated by Ames in the United States. Both these investigations are of great theoretical interest in themselves. But in addition, as Prof. Oldfield pointed out, they throw light on human behaviour in its everyday setting or in the clinic.

Prof. Knight and Mr. Laird were concerned to show that some rather naïve methodological assumptions about human motivation have led to logical difficulties. They suggested other interpretative schemes free from these difficulties. Again, it was emphasized that theoretical considerations of this kind are directly related to practical and clinical problems.

Finally, the present writer pointed out the increasing demand for professional psychologists and the inadequacy of present training methods in Great Britain to meet that demand. He suggested that the most useful development would consist in the expan. sion of training at the graduate level. It was agreed, however, that professional training should not be allowed to develop at the expense of fundamental research, nor should it be dissociated from the consideration of theoretical problems. Recent developments suggest that a good deal of research which has itself no directly practical aim will be of relevance in the practical field.

So far as any trend in general psychology was revealed by the three papers, it was this : that the different schools and aims and methodologies of psychology are disappearing, and the field is becoming much more unitary than was the case during the first part of the present century. J. DREver

\section{BRITISH MEDICINE AND THE CONTINENT, $1600-1850$} NEW exhibition at the Wellcome Historical
Continent, 1600-1850"-presents some interesting
contrasts with the "Medicine in 1850" exhibition
which it has replaced. The latter exhibition dealt
with the medicine of Europe during a limited period,
and was, in effect, a cross-section of medical thought.
The new exhibition is designed to illustrate not so
much the state of medicine at various times in
different countries, as the fluctuating influence which
the medical and scientific thought of the European
Continent exercised on British medicine at different
times, and vice versa.

A limited aspect of this approach was well brought out by Prof. Edvard Gotfredsen, professor of the history of medicine in the University of Copenhagen, in his address at the official opening of the exhibition, which took place before a distinguished company on October 19. Prof. Gotfredsen chose to deal with the relations between British and Danish medicine in the seventeenth and eighteenth centuries. He pointed out that in the seventeenth century medicine was very international, and that, as Latin was the international language of learning, medical students were enabled to travel all over Europe to hear famous teachers. Danish students of medicine of that time were forced to go abroad for much of their education, since a full medical education could not then be obtained at the University of Copenhagen. Of the Danish medical students who later became famous, those who visited Great Britain included Caspar Bartholin the elder, who wrote an important work on medical education and recommended foreign travel. Caspar's son Erasmus visited London and Oxford in 1647, and his brother-in-law, Olaff Worm, stayed for a year and a half in England.

The impact of Harvey's doctrine of the circulation was important in Denmark, since the new theory was introduced into that country by Thomas Bartholin, who also had considerable influence in spreading it on the Continent. The Dane, Holger Jacobæus, who later became professor of anatomy at Copenhagen, left some interesting descriptions of his life in London and Oxford. Prof. Gotfredsen also described in some detail the difficulties which arose in the Royal Society in attempts to confirm Stensen's work on the effects of ligating the descending aorta. In the first half of the eighteenth century the travels of Danish students had become less extensive, and in the second half they practically ceased. This fact was due to the improvement of facilities for clinical instruction in Copenhagen.

Prof. Gotfredsen was introduced by Dr. E. Ashworth Underwood, director of the Wellcome Historical Medical Museum, and a vote of thanks to him for his address was proposed by' Sir Wilson Jameson.

The exhibition commences with the British and Continental background at the end of the sixteenth century. This extremely interesting period, which was the prologue to all that followed in the seventeenth century, was marked by the overwhelming importance of Paris, Montpellier and Padua. Of the English works of this period, mention should be made of the superb copy of the 1545 edition of the "Anatomy" of Geminus. Another rare work which is shown, and which itself had considerable influence on the Continent, was Mouffett's "Theatre of Insects", 1634. One of the rarest books shown in this exhibition is the first edition of "The byrth of mankynde"; this is the translation of the well-known book by Eucharius Roesslin. This first edition was published in 1540 and the copy shown is one of the very few perfect copies in existence.

It need scarcely be said that the section of the exhibition on Harvey contains fine first editions of his works. Harvey's influence on the medicine of the Continent is brought out by the published works of his supporters and of his opponents.

The rise of the Royal Society is shown in an interesting manner, as also are its connexions with the scientific men of the Continent. In the later sections Boerhaave and Haller are well represented by fine copies of their works and a number of relics. The influence of the Hunters dominates the second part of the period dealt with, and in this connexion many will be interested in the extra-illustrated edition of Jesse Foot's "Life of Hunter". This contains many original wash drawings which illustrate events in the life of John Hunter.

The later sections of the exhibition contain books and exhibits which are now classics of the late eighteenth and early nineteenth century developments of the sciences which form the fundamental basis of modern medicine. 